\title{
Jean-Nicolas Illouz, Le Symbolisme
}

\section{Ida Merello}

\section{(2) OpenEdition}

\section{Journals}

\section{Edizione digitale}

URL: http://journals.openedition.org/studifrancesi/36522

DOI: 10.4000/studifrancesi.36522

ISSN: 2427-5856

\section{Editore}

Rosenberg \& Sellier

\section{Edizione cartacea}

Data di pubblicazione: 1 juillet 2005

Paginazione: 192

ISSN: 0039-2944

\section{Notizia bibliografica digitale}

Ida Merello, «Jean-Nicolas Illouz, Le Symbolisme», Studi Francesi [Online], 145 (XLIX | I) | 2005, online dal 30 novembre 2015, consultato il 20 avril 2021. URL: http://journals.openedition.org/studifrancesi/ 36522 ; DOI: https://doi.org/10.4000/studifrancesi.36522

\section{Questo documento è stato generato automaticamente il 20 avril 2021.}

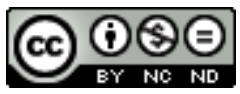

Studi Francesi è distribuita con Licenza Creative Commons Attribuzione - Non commerciale - Non opere derivate 4.0 Internazionale. 


\section{Jean-Nicolas Illouz, Le Symbolisme}

Ida Merello 


\section{NOTIZIA}

JEAN-NICOLAS ILlOUZ, Le Symbolisme, Paris, Le livre de poche, 2004, pp. 348.

1 Sembra impossibile che ci sia ancora spazio per un volume sul simbolismo, dopo l'abbondanza critica che lo ha accompagnato e seguito dal suo nascere fino ai nostri giorni; eppure l'A. è riuscito nell'impresa non facile di offrire un compendio sintetizzando una lettura storica, che si concentra su conquiste come la rivoluzione del linguaggio, e si districa abilmente nella diatriba sulla definizione e i termini cronologici del simbolismo - la scuola di Moréas, o un movimento più vasto che prende origine direttamente da Baudelaire e ha per principali esponenti Verlaine, Rimbaud e Mallarmé, che hanno scritto ben prima dei limiti temporali della scuola. Diviso in tre parti, nella prima descrive la situazione artistica e letteraria della fin de siècle, passando in rassegna i luoghi della cultura, dai caffè alle riviste, quindi ricorda le diverse influenze sul movimento, dai preraffaeliti a Gustave Moreau e sintetizzando bene i rapporti tra letteratura, pittura e musica, con attenzione ai rapporti con la cultura europea. Nella seconda si sofferma invece sulla natura dell'immaginario simbolista, più erudito che visionario, legato ad angosce esistenziali ed espressivo soprattutto di un atteggiamento manierista dei creatori. Il mito di Narciso e di Salomé, così esemplari della visione del mondo di allora, vengono citati più ampiamente, ma anche la descrizione dei paesaggi (interni ed esterni), ancora più sintetica, è ricca di indicazioni precise e puntuali. L'A. non dimentica di indagare i rapporti tra simbolismo e romanticismo, soprattutto tedesco, nonché con la filosofia, da Schopenhauer da Hartmann fino a Bergson. Soffermandosi invece sugli autori che hanno influito sul movimento, l'A. riprende in un'ottima sintesi i legami con Baudelaire, Rimbaud, Mallarmé, prima di procedere a una descrizione del credo simbolista e delle diverse soluzioni formali, fino al verso libero. Il testo è corredato da un'antologia di testi teorici e da una buona bibliografia. 